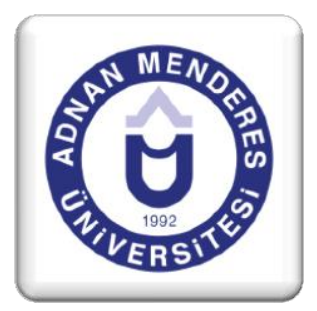

\title{
Budget Sustainability of Local Governments in Turkey
}

\author{
Hakan Hotunluoğlu ${ }^{1}$
}

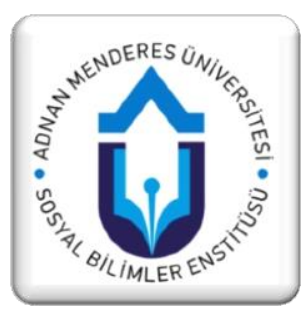

\section{ABSTRACT}

Budgets and structures of local governments, which are formed in order to present local public services, vary from country to country. The share of Local governments' budget in Turkey, which has a unitary state system, is around $\% 10$ in total budget. In analysing budget sustainability, local governments should be taken into consideration. This study empirically investigates budget sustainability of 81 provinces' local governments. The results have found majority of local governments have low budget sustainability.

Keywords: Local government budget, budget sustainability, panel data.

\section{Türkiye’de Yerel Yönetimlerin Bütçe Sürdürülebilirliği}

\section{ÖZET}

Yerel kamusal hizmetlerin sunumunu için oluşturulmuş yerel yönetimlerin yapısı ve sahip oldukları bütçe ülkeden ülkeye farklılık göstermektedir. Üniter bir yapıya sahip Türkiye'de yerel yönetimlerin bütçeleri toplam bütçe içerisinde $\% 10$ seviyesindedir. Bütçelerin sürdürülebilirliğinin analiz edilirken yerel yönetimlerin de dikkate alınması önemli bir noktadır. Bu çalışmada Türkiye'de 81 yerel yönetimin bütçe sürdürülebilirliği ampirik olarak araştırılmıştır. Yerel yönetimlerin büyük bölümünün sürdürülebilirliği zayıf bütçeye sahip oldukları tespit edilmiştir.

Anahtar Kelimeler: Yerel yönetim bütçesi, bütçe sürdürülebilirliği, panel veri.

\footnotetext{
${ }^{1}$ Yrd.Doç.Dr., Adnan Menderes Üniversitesi Aydın İktisat Fakültesi İktisat Bölümü , hakanhotunlu@gmail.com
} 


\section{Introduction}

Provision of public services in the world is shared between central and local governments. Theoretically it is suggested that public services should be provided by central governments whereas local services should be provided by local governments. However governmental systems of countries, their political structure, geographical size, social and cultural properties all influence the distribution of public services between central and local governments. Turkey has a unitary structure in terms of provision of public services. Central government is responsible for most of these services. Therefore, central government uses much of the budget. The share of expenditure of local governments such as municipalities and provincial special administrations in state budget and in GDP are presented in Figure 1.

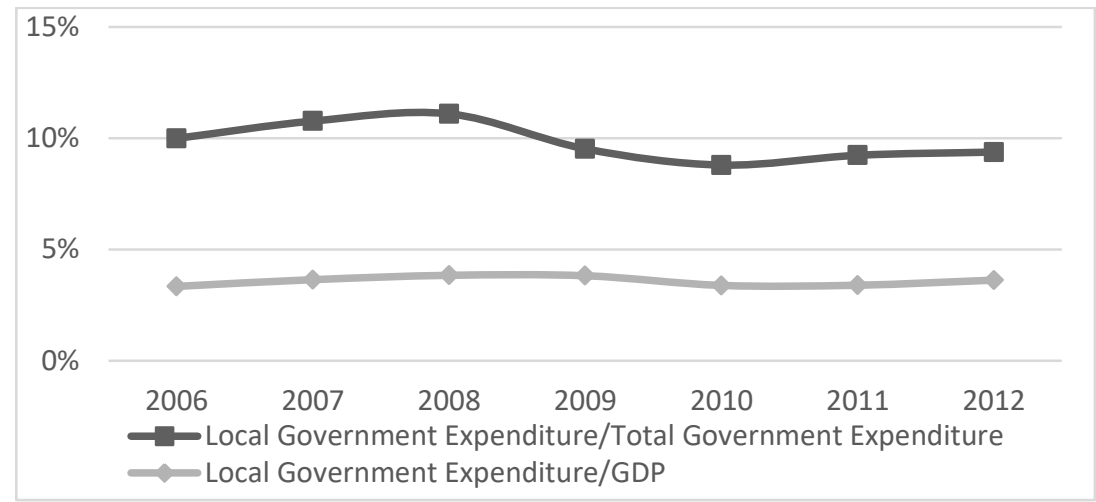

Figure 1: Local Government Expenditure

According to Fig. 1, the share of local governments in Turkey in total state expenditure fluctuated around 10\% between 2006 and 2012. Similarly, the share of local governments in GDP has not changed significantly and fluctuated around $4 \%$ for the same period.

In analysing budget sustainability, it is not enough to use only total budget data as $10 \%$ of public budget in Turkey is used by local governments. In addition, financial status of each province should be considered for sustainability as local government's share from the budget is distributed to provincial special administrations in 81 provinces. In the literature, there is no research on budget sustainability in accordance with local governments in Turkey. Hence, this study investigates budget sustainability of local governments in Turkey for the 200620012 period.

\section{Literature}

There are several studies examining budget sustainability of local governments in the international literature. Schoeman (2011), in a study on 237 municipalities in South Africa, identified that one third of the municipalities was not able to receive amount of revenue. According to this study, municipal administrations lack their own sources of income in order to achieve financial sustainability and they could only balance their budget through subsidies of central government. Mahdavi and Westerlund (2011) conducted a study between 1961 and 2006 in 47 states of the US. They found out that state budgets are strictly sustainable. Burret, H. T., Feld, L. P., and Köhler, E. A. (2014)'s study consisted a local government research that was done in 10 region of Germany between 1950 and 2011. They identified that only one region's budget is strictly sustainable. Bröthaler et al (2014) studied on 2400 
municipalities in Austria between 1992 and 2010, emphasized that budgets of municipalities are sustainable in the long run. Mahdavi (2014) did a research on 48 states of the US between 1961 and 2008 and concluded that they all have sustainable fiscal structures.

In Turkey, research on budget sustainability is limited with central government budget. Azgün and Taşdemir (2006), Aslan (2009) Ceylan (2010), Kayalıdere (2011) and Peker and Göçer (2012) found out that the budget is sustainable. Özmen and Koğar (1998), Günaydın (2003), Kuştepeli and Önel (2005), Göktaş (2008), Payne, Mohammadi and Çak (2008), and Yıldırım and Özcan (2011) identified that the budget is weakly sustainable. However, Arısoy and Ünlükaplan (2010), Şen, Sağbaş and Keskin (2010) and Hepsağ (2011) concluded that central government budget is unsustainable.

There are only a few results concerning that central government budget in Turkey is sustainable. Most results indicate that it is weakly sustainable or unsustainable. Tekeli and Hotunluoğlu (2014) empirically investigate budgets of local governments. In this study, they examined sustainability of central and local government budgets between 1975 and 2012 through annual data. According to this study, central and local government budgets are weakly sustainable. Nevertheless, as these data belong to total expenditure and revenue of local governments, sufficient information for each local government concerning sustainability is not available.

\section{3- Data and Model}

Data of this study include data obtained from 81 provinces between 2007Q1 and 2014Q3. Data concerning budget revenue $(L R R)$ and expenditure $(L R E)$ of 81 provinces are real data excluding inflation. Budget revenue and expenditure were obtained from General Directorate of Public Accounts (GDPA).

In analysing budget sustainability for local governments, the dynamic budget deficit method, which was developed by Hakkio-Rush (1991), was used. Accordingly, if budget revenue and expenditure in the long run are co-integrated and predictable revenue coefficient is " 1 ", then budget deficit is sustainable. If this coefficient is lower than " 1 ", then budget is considered unsustainable. Quintos (1995) acknowledged that if this value is 1, budget is strictly sustainable, if it is between 0 and 1 then it is weakly sustainable. The equation (1) derived for this method is shown below

$$
L R E_{t}=\mu+\beta L R R_{t}+\varepsilon_{t}
$$

\section{Unit Root Tests}

Data sets used for budget sustainability of local governments contain 31 data on the time dimension for each province. It can be said that time dimension is enough for root tests. Unit Root Test employed for the LRE and LRR variables of the study is shown on Table 1 below (Breitung, 2000; Choi, 2001; Hadri, 2000; Im, Pesaran, and Shin, 2003; Levin, Lin, and James Chu, 2002; Maddala and Wu, 1999). 
Table 1: Unit Root Test Results (Level)

\begin{tabular}{|l|l|l|l|l|l|l|}
\hline \multirow{2}{*}{} & Unit Root Tests & $\begin{array}{l}\text { Individual } \\
\text { intercept }\end{array}$ & $\begin{array}{l}\text { Individual } \\
\text { Intercept and } \\
\text { Trend }\end{array}$ & None & $\begin{array}{l}\text { Cross } \\
\text { sections }\end{array}$ & Obs \\
\hline \multirow{5}{*}{ LRE } & Levin, Lin and Chu t* & 11.652 & 38.697 & 12.030 & 81 & 2106 \\
& Breitung t-stat & & $-6.451 * * *$ & & 81 & 2025 \\
& Im, Pesaran and Shin W-stat & 1.977 & $-1.536 *$ & & 81 & 2106 \\
& ADF - Fisher Chi-square & 103.876 & 143.123 & 18.496 & 81 & 2106 \\
& PP - Fisher Chi-square & $1141.020^{* * *}$ & $4126.160 * * *$ & 20.387 & 81 & 2430 \\
\hline
\end{tabular}

During the unit root test, as shown on table, data consisted of quarters. Therefore, their lag lengths were assumed as 4 . According to unit root test results, generally variables are not stationary. Table 2 presents unit root test results of the first difference of data.

Table 2: Unit Root Test Results (First Difference)

\begin{tabular}{|c|c|c|c|c|c|}
\hline Unit Root Tests & $\begin{array}{l}\text { Individual } \\
\text { intercept }\end{array}$ & $\begin{array}{l}\text { Individual } \\
\text { Intercept and } \\
\text { Trend }\end{array}$ & None & $\begin{array}{l}\text { Cross } \\
\text { sections } \\
\end{array}$ & Obs \\
\hline Levin, Lin and Chu t* & 116.988 & 144.990 & $-23.605 * * *$ & 81 & 2025 \\
\hline Breitung t-stat & & 8.424 & & 81 & 1944 \\
\hline Im, Pesaran and Shin W-stat & $-13.414 * * *$ & $-8.337 * * *$ & & 81 & 2025 \\
\hline ADF - Fisher Chi-square & $465.894 * * *$ & $302.323 * * *$ & $689.131 * * *$ & 81 & 2025 \\
\hline PP - Fisher Chi-square & $2322.560 * * *$ & $15918.100 * * *$ & $12602.400 * * *$ & 81 & 2349 \\
\hline Levin, Lin and Chu t* & 83.425 & 99.906 & -22.643 & 81 & 2025 \\
\hline Breitung t-stat & & 4.974 & & 81 & 1944 \\
\hline Im, Pesaran and Shin W-stat & $-10.906 * * *$ & $-5.722 * * *$ & & 81 & 2025 \\
\hline ADF - Fisher Chi-square & $384.619 * * *$ & $233.555 * * *$ & $636.407 * * *$ & 81 & 2025 \\
\hline PP - Fisher Chi-square & $2051.690^{* * *}$ & $18458.400 * * *$ & $14089.600 * * *$ & 81 & 2349 \\
\hline
\end{tabular}

Notes: Significance level: ***, $1 \% ; * *, 5 \% ; *, 10 \%$.

According to stationary analysis, first difference series seen on Table 2 are stationary.

\section{Panel Co-integration Test}

The relationship between variables, which are used for sustainability analysis, should be investigated in a long term. Long term relationship between non-stationary variables are examined through co-integration analysis (Pedroni, 1999, 2004; Westerlund and Edgerton, 2007; Westerlund, 2008, 2007). This study benefited from the Durbin-H method, developed by Sterlund (2008). Two tests are applied in this test; the first one is the Durbin-H Group test, which allows change between autoregressive parameters and the second one is the 
Durbin-H Panel test in which parameters are constant. (Westerlund, 2008). If the results of these tests are statistically significant, it can be interpreted that variables have long-term relationship.

Table 3: Co-integration Tests

\begin{tabular}{|l|l|l|}
\hline Test & Stat & p-value \\
\hline Durbin-H Group & 9873.220 & 0.000 \\
Durbin-H Panel & 202.567 & 0.000 \\
\hline
\end{tabular}

Table 3 presents test results of Durbin-H co-integration tests between variables. According to test results, there is a long-term co-integration between revenue and expenditures of local governments.

\section{Co-integration Coefficients Estimation}

Co-integration between variables requires estimation of long-term co-integration coefficients. These coefficients determine co-integrated relationship between budget revenue and expenditures, in other words they determine sustainability. Long term co-integration coefficients were estimated through Correlated Effects Mean Group Estimator (CCE) (Pesaran, 2007) and Augmented Mean Group Estimator (AMG) (Eberhardt and Bond, 2009; Eberhardt and Teal, 2010). First of all, CCE and AMG long term coefficients were estimated for the panel. The results are shown on table 4 .

Table 4: Long-term co-integration coefficients

\begin{tabular}{|cc|cc|}
\hline \multicolumn{2}{|c|}{ CCE } & \multicolumn{2}{c|}{ AMG } \\
\hline Coef & t-stat. & Coef & t-stat. \\
\hline $0.404 * * *$ & 11.730 & $0.471 * * * *$ & 13.210 \\
\hline \multicolumn{2}{|c|}{ Notes: Significance level: ***, $1 \% ; * *, 5 \% ; *, 10 \%}$.
\end{tabular}

Long term coefficients between 0 and 1 are statistically significant. Therefore, according to long term co-integration status of 81 provinces in Turkey local government budgets are weakly sustainable.

Through CCE and AMG, long-term co-integration coefficient was estimated for each group (for each local government) (Appendix I and II).If coefficients, that are estimated through CCE, are equal to 1 or more than 1 and significant, then there is Strict Budget Sustainability, if they are between 0 and 1 and significant, there is Weak Budget Sustainability, if they are less than 0 and significant we can talk about Unsustainability. If coefficients are less than 0 and not significant, then it is shown as Not Significant (see Figure 2) 


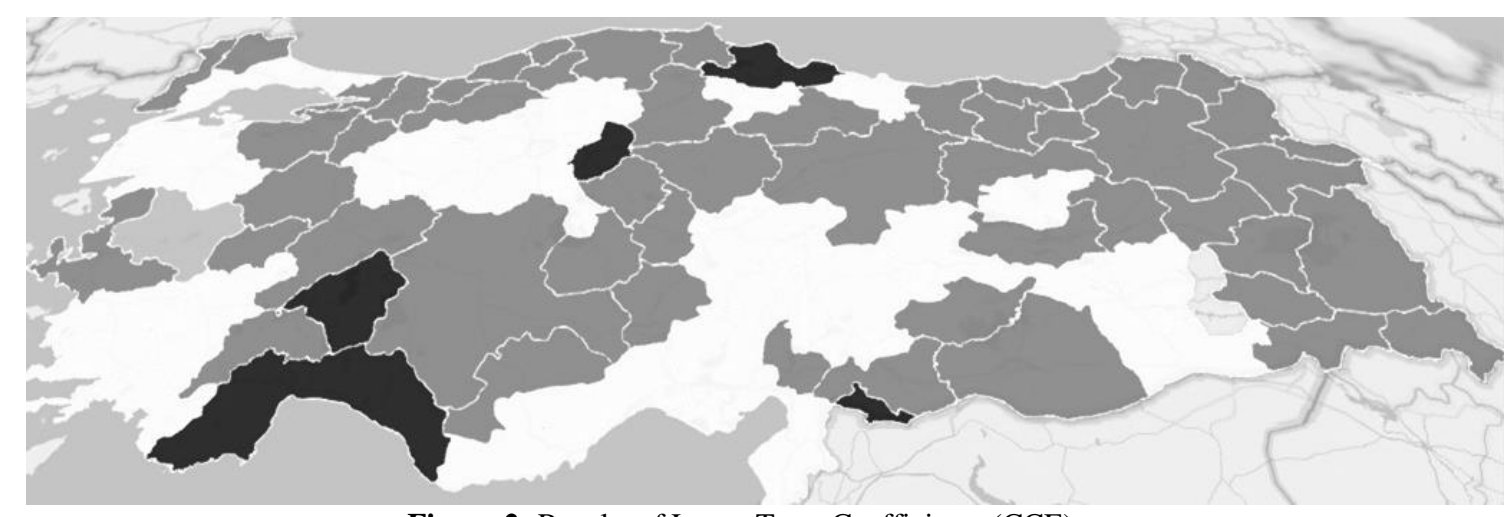

Figure 2: Results of Long- Term Coefficients (CCE)

According to CCE co-integration data, which are shown as a map graph (Figure 2), budgets of Antalya, Kırıkkale, Isparta, Samsun and Kilis have strict sustainability. The city of Manisa's budget is certainly unsustainable. It was also found out that budgets of 53 local governments have weak sustainability.

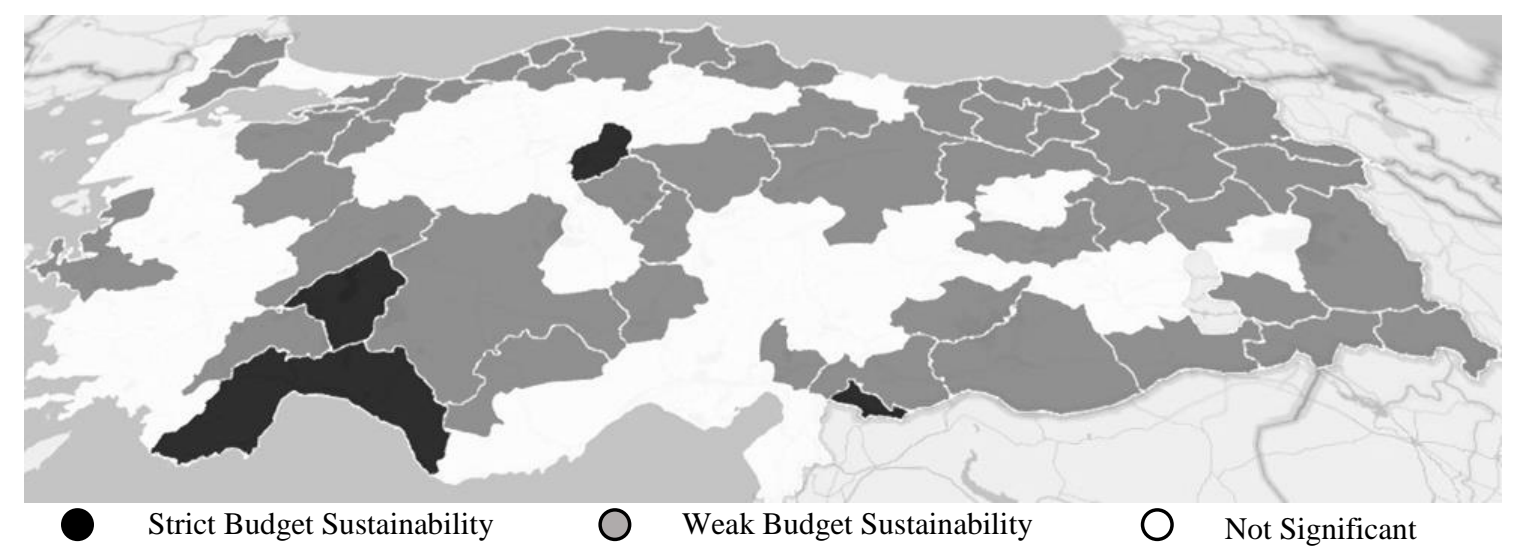

Figure 3: Results of Long-Term Coefficients (AMG)

Co-integration coefficients, which were estimated through AMG, are shown on Figure 3. According to estimated results and in parallel with AMG estimations, budgets of Antalya, Isparta, Kırıkkale and Kilis have strict sustainability. According to these estimations, no city with unsustainable budget was identified. In addition, it was found out that budgets of 51 local governments have weak sustainability.

\section{Conclusion}

As local government budgets in Turkey constitute $10 \%$ of budget size, it is important that local governments should also be taken into consideration in analysing budget sustainability. The study identified that among 81 local governments; approximately $5 \%$ of the provinces have sustainable budgets. $65 \%$ of them have weak budget sustainability. Only one local government has certainly unsustainable budget. According to these results, it can be stated that there are issues concerning budget sustainability of local government in Turkey. In order to overcome potential problems in the future, it is essential to take measures to increase the revenue and revise expenditures. 


\section{REFERENCES}

ARISOY, İ. \& ÜNLÜKAPLAN, İ. (2010). Türkiye'de Mali Aç1kların Sürdürülebilirliği ile Kamu Gelirleri ve Harcamaları İlişkisinin Analizi. Maliye Dergisi, 159 (TemmuzAralık): 444-462

ASLAN, A. (2009). Bütçe Açığı Sürdürülebilirliğinin Dinamik Analizi: Türkiye Örneği. Maliye Dergisi, 157, 227-234.

AZGÜN, S. \& Taşdemir, M. (2006). Bütçe Açıklarının Sürdürülebilirliği: Zamanlararası Borçlanma Kısıtının Testi (1980-2004). Atatürk Üniversitesi İ̈BF Dergisi, 20 (2): 3547.

BREITUNG, J. (2000). The local power of some unit root tests for panel data. Içinde Advances in Econometrics, Vol. 15: Nonstationary Panels, Panel Cointegration, and Dynamic Panels, JAI (ss. 161-178). Press.

CEYLAN, R. (2010). Türkiye'de Mali Sürdürülebilirlik Göstergeleri İstikrarlı mı?. Maliye Dergisi, 158, 388-397.

CHOİ, I. (2001). Unit root tests for panel data. Journal of International Money and Finance, 20(2), 249-272. doi:10.1016/S0261-5606(00)00048-6

EBERHARDT, M., \& BOND, S. (2009, Ekim 7). Cross-section dependence in nonstationary panel models: a novel estimator [MPRA Paper].

EBERHARDT, M., \& TEAL, F. (2010). Aggregation versus Heterogeneity in CrossCountry Growth Empirics (CSAE Working Paper Series No. 2010-32). Centre for the Study of African Economies, University of Oxford.

GÖKTAŞ, Ö. (2008). Türkiye Ekonomisinde Bütçe Açığının Sürdürülebilirliğinin Analizi. İstanbul Üniversitesi Íktisat Fakültesi Ekonometri ve İstatistik Dergisi, 8, 45-64.

GÜNAYDIN, E. (2003). Analysing the Sustainability of Fiscal Deficits in Turkey. Hazine Dergisi, 16, 1-14.

HADRİ, K. (2000). Testing for stationarity in heterogeneous panel data. Econometrics Journal, 3(2), 148-161. doi:10.1111/1368-423X.00043

HEPSAĞ, A. (2011). Mali Politikaların Sürdürülebilirliğinin Yapısal Kırılmalı Periyodik Birim Kök Testi İle Analizi: Türkiye Örneği Doğuş Üniversitesi Dergisi, 12 (1) 2011, $32-45$

IM, K. S., PESARAN, M. H., \& SHIN, Y. (2003). Testing for unit roots in heterogeneous panels. Journal of Econometrics, 115(1), 53-74. doi:10.1016/S0304-4076(03)00092-7

KAYALIDERE G (2011). Türkiye'nin Maliye Politikalarının Bütçe Kısıtı Teorisi Açısından Sürdürülebilirliği: Var Analizi. İstanbul Üniversitesi İktisat Fakültesi Maliye Araştırma Merkezi Konferansları 55. Seri / Y1l 2011-[1]:35-60.

KUŞTEPELİ, Y. \& Önel, G. (2005). Fiscal Deficit Sustainability with a Structural Break: An Application to Turkey. Eastern Mediterranean University Review of Social, Economic and Business Studies, 5/6, 189-208.

LEVIN, A., LIN, C.-F., \& JAMES CHU, C.-S. (2002). Unit root tests in panel data: asymptotic and finite-sample properties. Journal of Econometrics, 108(1), 1-24. 
MADDALA, G. S., \& WU, S. (1999). A Comparative Study of Unit Root Tests with Panel Data and a New Simple Test. Oxford Bulletin of Economics and Statistics, 61(S1), 631-652. doi:10.1111/1468-0084.0610s1631

ÖZMEN, E. \& KOĞAR, Ç.İ. (1998). Sustainability of Budget Deficits in Turkey with a Structural Shift. METU Studies in Development, 25 (1), 107-27.

PAYNE, J., MOHAMMADİ, H. \& ÇAK, M. (2008). Turkish Budget Deficit Sustainability and the Revenue-expenditure Nexus. Applied Economics, 40(7), 823-830.

PEDRONI, P. (1999). Critical values for cointegration tests in heterogeneous panels with multiple regressors. Oxford Bulletin of Economics and statistics, 61(S1), 653-670.

PEDRONI, P. (2004). Panel Cointegration: Asymptotic And Finıte Sample Properties Of Pooled Time Series Tests With An Application To The Ppp Hypothesis. Econometric

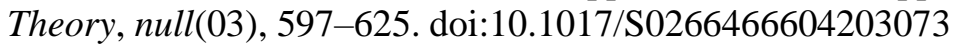

PEKER, O. \& GÖÇER, İ. (2012). Bütçe Açılarının Ampirik Analizi. Yönetim ve Ekonomi, 19(1): 163-178.

PESARAN, M. H. (2007). A simple panel unit root test in the presence of cross-section dependence. Journal of Applied Econometrics, 22(2), 265-312.

WESTERLUND, J. (2007). Testing for Error Correction in Panel Data*. Oxford Bulletin of Economics and Statistics, 69(6), 709-748. doi:10.1111/j.1468-0084.2007.00477.x

WESTERLUND, J. (2008). Panel cointegration tests of the Fisher effect. Journal of Applied Econometrics, 23(2), 193-233.

WESTERLUND, J., \& EDGERTON, D. L. (2007). A panel bootstrap cointegration test. Economics Letters, 97(3), 185-190. doi:10.1016/j.econlet.2007.03.003 